The Religious Roots of The SYRIAN CONFLICT 


\section{Twenty-First Century Perspectives on War,}

Peace, and Human Conflict

Series Editor: Charles P. Webel

Terror, Terrorism, and the Human Condition

By Charles P. Webel

The Ethics and Efficacy of the Global War on Terrorism:

Fighting Terror with Terror

Edited by Charles P. Webel and John A. Arnaldi

War and Delusion: A Critical Examination

By Laurie Calhoun

The Religious Roots of the Syrian Conflict: The Remaking of the Fertile Crescent

By Mark Tomass 


\title{
The Religious Roots of The SYRIAN CONFLICT
}

The Remaking of the Fertile

CRESCENT

\author{
Mark Tomass
}




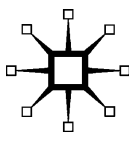

THE RELIGIOUS ROOTS OF THE SYRIAN CONFLICT

Copyright (C) Mark Tomass 2016

Softcover reprint of the hardcover 1st edition 2016 978-1-137-53149-0

All rights reserved. No reproduction, copy or transmission of this publication may be made without written permission. No portion of this publication may be reproduced, copied or transmitted save with written permission. In accordance with the provisions of the Copyright, Designs and Patents Act 1988, or under the terms of any licence permitting limited copying issued by the Copyright Licensing Agency, Saffron House, 6-10 Kirby Street, London EC1N 8TS.

Any person who does any unauthorized act in relation to this publication may be liable to criminal prosecution and civil claims for damages.

First published 2016 by PALGRAVE MACMILLAN

The author has asserted their right to be identified as the author of this work in accordance with the Copyright, Designs and Patents Act 1988.

Palgrave Macmillan in the UK is an imprint of Macmillan Publishers Limited, registered in England, company number 785998, of Houndmills, Basingstoke, Hampshire, RG216XS.

Palgrave Macmillan in the US is a division of Nature America, Inc., One New York Plaza, Suite 4500, New York, NY 10004-1562.

Palgrave Macmillan is the global academic imprint of the above companies and has companies and representatives throughout the world.

ISBN 978-1-349-70886-4

E-PDF ISBN: 978-1-137-52571-0

DOI: $10.1057 / 9781137525710$

Distribution in the UK, Europe and the rest of the world is by Palgrave Macmillan ${ }^{\circledR}$, a division of Macmillan Publishers Limited, registered in England, company number 785998, of Houndmills, Basingstoke, Hampshire RG21 6XS.

Library of Congress Cataloging-in-Publication Data

Names: Tomass, Mark, 1961- author.

Title: The religious roots of the Syrian conflict : the remaking of the Fertile Crescent / Mark Tomass.

Description: New York, NY : Palgrave Macmillan, 2016. | Series:

Twenty-first century perspectives on war, peace, and human conflict | Includes bibliographical references and index.

Identifiers: LCCN 2015027216

Subjects: LCSH: Syria—Religion-History. | Islamic sects—Syria—History. | Christian sects-Syria—History. | Jewish sects-Syria-History. | SyriaHistory-Civil War, 2011—Religious aspects. | BISAC: POLITICAL SCIENCE / International Relations / General. | RELIGION / Religion, Politics \& State. | SOCIAL SCIENCE / Sociology of Religion. | SOCIAL SCIENCE / Islamic Studies. | SOCIAL SCIENCE / Regional Studies.

Classification: LCC BL2340 .T66 2016 | DDC 306.6095691—dc23 LC record available at http://lccn.loc.gov/2015027216

A catalogue record for the book is available from the British Library. 
In memory of the minds and bodies sacrificed on the altar of what was once upon a time the Cradle of Civilization 


\section{CONTENTS}

List of Illustrations $\quad$ ix

Preface $\quad$ xi

Acknowledgments xiii

Introduction 1

1 The Significance of Religious Identity 9

2 The Fertile Crescent Meets the Muslim Arabs 27

3 Formation of the Jewish Identity 39

4 Formation of Christian Sectarian Identities 45

5 Formation of Muslim Sectarian Identities 65

6 The Islamization of the Fertile Crescent 97

7 Social and Psychological Origins of Religious Conflict $\quad 107$

8 The New Media and the Islamic Awakening 137

9 From the Arab Spring to the Revolt of the Sunna 151

10 The Remaking of the Fertile Crescent 187

11 Aleppo War Photographs, 2012-14 213

Notes 229

Index 269 


\section{ILLUSTRATIONS}

\section{FiguRES}

2.1 Map of the Fertile Crescent of antiquity, 4000-1500 BC

2.2 Map of the Fertile Crescent divided between the Byzantine and Persian (Sasanian) Empires on the eve of the Muslim Arab conquest, AD 635

9.1 Map of the Middle East

9.2 Map of Syria

9.3 Map of the Fertile Crescent with territories in Syria, Lebanon, and Iraq controlled by rival forces $\quad 180$

11.1 The Old City and the Citadel of Aleppo, ca. $2013 \quad 213$

11.2 An outdated slogan 214

11.3 A father marks his son's grave 215

11.4 A child's grave in a repurposed park 216

11.5 Where they lived 217

11.6 Remains of homes in the Old City 218

11.7 Boy and mortar shell 219

11.8 Mortar shell in the street 220

11.9 A soldier leads them home 221

11.10 Soldier watching the street 222

11.11 The Citadel of Aleppo: The view from what was the

11.12 Prayer in a courtyard 224

11.13 A desecrated mosque $\quad 225$

11.14 An Armenian church in ashes 226

11.15 A Christian church and school destroyed 226

11.16 A landmark leveled 227

\section{TABLES}

1.1 Categories of identity 10

7.1 Fifth- to seventh-century Christology 108 
7.2 Muslim sects 113

7.3 Levels and substance of religious conflict 122

7.4 Identification, conformity, and prejudice 127

7.5 Identity and conformity 135

9.1 A sample of popular Facebook pages $\quad 176$ 


\section{PREFACE}

$\mathrm{T}$

his book is intended for Western college-educated readers seeking an alternative to the mainstream narrative describing the Syrian conflict. It is a broad interpretation of events offered by a Syrian native, born, raised, and educated in Aleppo, Syria. It accounts for key periods spanning the last two millennia that played a role in defining the current scene in Syria and the Fertile Crescent.

The Religious Roots of the Syrian Conflict is a new title for an old project that the author conceived in 1998 under the title "The Unmaking of the Nation-States of the Near East." The motive for the initial project was to contemplate possible scenarios that would lead to the breakdown of Syria and Iraq into sectarian states parallel to the sectarian breakdown of Lebanon following its 1975-90 civil war. ${ }^{1}$ Conceiving a repeat of the Lebanese scenario was inspired by the rise of the satellite-based al-Jazeera television channel in 1997. Al-Jazeera ushered in a new era in public discourse by surmounting state censorship and making privately held religious beliefs public. Its legitimization of sectarian rhetoric at the expense of secular nationalist ones gave the first sign that the region could be heading toward sectarian discord. ${ }^{2}$ That trend was amplified by the emergence of subsequent new Internet-based media. The combined effects of the politicization of the Shìa identity after the establishment of the Shìa theocracy in Iran, the US invasion of Iraq that undermined Sunni power, and the prevalence of informal sectarian institutions further weakened the fragile secular institutions of the nation-states of the Fertile Crescent and paved the way for an intra-Muslim civil war. ${ }^{3}$

Much of the groundwork for this book on the formation of sects and the social psychological origins of religious conflict was done between 2009 and 2010 in preparation for a course entitled Exclusionist Religious Identities and Civil Conflict in the Middle East taught in Spring 2011. ${ }^{4}$ It aims to explain the importance and significance of religious and sectarian identification to the people of Geographical Syria in particular and of the Middle East at large. It employs historical narratives to outline the circumstances associated 
with the formation of religious sects and uses ethnographic accounts to interpret the meanings that people attribute to their sectarian identities. Its methodology is based on the belief that shared experiences create a basis for comprehending the perspectives of others.

The author's descriptions and analyses draw from his direct observations, which have been gained through face-to-face interaction as well as documentary sources. On the basis of those observations, the author describes how sectarian identity affects an individual's interpretation of world events and his or her reactions to them. Experience has shown the author that Middle Easterners tend to speak candidly with those they trust. Such trust requires the kind of direct, repeated, and informal interaction that the author has had the privilege to experience.

Because this book's narrative regards religious identity as the dominant determinant of political allegiances in the Middle East, it does not tackle the presence of additional layers of conflict, especially a language-based nationalism that demarcates proponents of Arab, Armenian, Assyrian (Syrio-Aramaic), Kurdish, and Turkmen identities. Some readers may especially be dismayed by the absence of analysis of the Kurdish nationalist movement and its implication for the region of the Fertile Crescent. However, from the perspective of this book, the rise of Kurdish nationalism and the Kurd's strive for a separate state does not obscure the religious identity of the Kurds, or the manner in which that identity is viewed in the region by non-Kurdish Muslims or by non-Muslims. While at the contemporary stage of their history, the overwhelming numbers of Kurds are prioritizing their Kurdish over their sectarian identities, the autonomous Kurdish region in Iraq contains an array of religious groups that are susceptible to similar intraMuslim discord that non-Kurdish Muslims are currently experiencing.

Moreover, because of the vast amount of literature that focuses on the Arab-Israeli conflict, this book does not engage that conflict directly. It provides a brief narrative of the formation of the Jewish identity and then confines its analyses to the implications of Israel's existence and military interventions in the region to the intra-Muslim sectarian conflict.

Finally, because of the sensitivity of the material discussed in this book, the author discloses that he is independent of any of the local or international propaganda outlets of the various forces that are engaged in the Syrian conflict and are influencing Western public opinion through news media, research centers, and think tanks. Furthermore, the author has not received any material or other form of support for the substance of this work from any Western or Middle Eastern political entity. 


\title{
ACKNOWLEDGMENTS
}

\begin{abstract}
$\mathrm{T}$ he author thanks Hannibal Travis for substantive comments on the manuscript. He thanks Sebastian Brock, for his many insights and clarifications throughout the last decade on the religious and cultural milieu in Syria during the period of late antiquity, and Robert Hoyland, for clarifications on the terminology used in the Syriac chronicles of the seventh century.

The author thanks E. Roger Owen of Harvard University's Center for Middle Eastern Studies for his multiple sponsorships of the author's visiting research fellowships to the center, which allowed him to perform the groundwork research for this book. Many thanks are also due to Harvard University Extension School's Faculty Aide Program that supplied the author with talented graduate students who provided editorial suggestions. Among those, special thanks are due to Lia Oppedisano for reviewing this manuscript and to Benaiah Sunde for suggestions on its distant ancestors.

The author also thanks Sargon Donabed, Efrem Yildiz, Pavlina Nekulova, Marielle Costanza and Charles Webel for comments and William Evans for conversations on the US political perspective of the Middle East. None of the above carries any responsibility for the substance of the analysis presented. Special thanks to George Hako for providing information on the current violence in Syria.

Many thanks to Hagop Vanesian for his contribution of 16 photos he captured of the war zone in old quarters of the city of Aleppo, Syria.
\end{abstract}

